\title{
INORGANIC AND ORGANIC CONTAMINATION IN SEDIMENT FROM IZMIR BAY (TURKEY) AND MYTILENE HARBOR (GREECE)
}

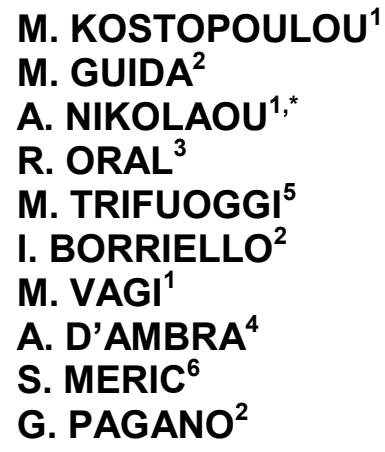

Received: $26 / 09 / 12$

Accepted: $30 / 10 / 12$

\author{
${ }^{1}$ Department of Marine Sciences, University of the Aegean \\ GR-81100 Mytilene, Greece \\ ${ }^{2}$ Federico II University, Department of Biological Sciences \\ Section of Hygiene, I-80134 Naples, Italy \\ ${ }^{3}$ Ege University, Faculty of Fisheries \\ TK-35100 Bornova, Izmir, Turkey \\ ${ }^{4}$ Federico II University, Department of Mathematics \& Statistics \\ I-80126 Naples, Italy \\ ${ }^{5}$ Federico I/ University, Department of Chemistry \\ I-80126 Naples, Italy \\ ${ }^{6}$ Namık Kemal University, Çorlu Engineering Faculty \\ Environmental Engineering Department, Çorlu, Tekirdağ, Turkey
}

*to whom all correspondence should be addressed: e-mail: nnikol@aegean.gr

\begin{abstract}
Marine sediment contamination was evaluated in a set of sediment specimens collected from Izmir Bay (Turkey) and from Mytilene Harbor (Greece) in the Aegean Sea. Eight sediment specimens from Izmir (\#IZ to \#IZ8) and seven sediment specimens from Mytilene (\#MYT1 to \#MYT7) were analyzed for their content in different classes of contaminants, i.e. inorganics, organic carbon (OC), and seven polycyclic aromatic hydrocarbons (PAHs). Significantly higher levels of inorganic contaminants were detected in Izmir vs. Mytilene sediment, and the highest inorganic contamination was detected in the innermost sampling sites in Izmir Bay, namely sites \#IZ1 to \#IZ4. This was the case for Al, As, Cr, $\mathrm{Cu}, \mathrm{Fe}, \mathrm{Li}, \mathrm{Mn}, \mathrm{Pb}, \mathrm{Ti}$ and $\mathrm{Zn}$. Granulometric analysis, $\mathrm{OC}$ and individual PAH congeners failed to show any significant differences between total Mytilene and total Izmir Bay sediment samples. Nevertheless, the sum of PAHs in sites \#IZ2 to \#IZ4 displayed significantly higher levels both vs. the other Izmir sites and vs. all Mytilene sediment samples. The overall results point to higher pollution status in Izmir Bay, especially in the innermost sampling sites, compared to Mytilene Harbor, detected as inorganic contamination and as PAH contamination in some Izmir sampling sites.
\end{abstract}

KEYWORDS: marine sediment; harbor pollution; inorganics; polycyclic aromatic hydrocarbons. Environmental Engineering Department, Çorlu, Tekirdağ, Turkey

\section{INTRODUCTION}

The anthropogenic contamination of coastal sediments represents a major environmental threat both to marine biota and to human health, and requires thorough evaluation both under the analytical and the toxicological viewpoints in the prospect of appropriate risk assessment and of planning suitable amendment strategies (Chapman and Wang 2001; Chapman et al., 2002; Chen and White 2004; Ho et al., 2002; He and Morrison 2001; Pagano et al., 2001, Kalantzi and Alcock, 2012; Thomaidis et al., 2012; Petreas et al., 2012).

Two major contaminant categories investigated in the marine environment worldwide are PAHs and heavy metals, due to their high toxicity and environmental persistence, and due to their inclusion as priority substances in the Water Framework Directive 2000/60/EC (EC 2000). Regarding the Mediterranean Sea, pollution studies of sediment contamination have been focused on several pollutant families throughout Mediterranean (Bertolotto et al., 2003; De Luca et al., 2005; Díez and 
Bayona 2009; Esen et al., 2010; Kanaki et al., 2007; Khairy et al., 2009; Kucukksezgin et al. 2006; Lipiatou et al., 1997; Martin et al., 2009; Bloutsos and Giannopoulos, 2011; Savvidis et al., 2011).

The present study was aimed at evaluating the contamination status of marine surface sediments from two Mediterranean areas (Figure 1), namely Izmir Bay (Western Turkey) and Mytilene Harbor (NE Aegean, Lesbos Island, Greece). The selection of sampling sites was to examine sources of pollution as they were identified by means of previous data (Aksu et al., 1998; Darilmaz and Kucuksezgin 2007; Kontas et al., 2004; Kontas, 2006; Kucuksezgin et al., 2006; Sunlu et al., 2008) by a relatively broad spatial coverage of the studied areas thus allowing an assessment of their sediment quality (Casado-Martinez et al., 2006). Analyses were carried out for the determination of conventional parameters (grain size, organic carbon), along with a set of inorganic (19 elements) and organic contaminants (7 PAH congeners) being analyzed for. The results showed different pollution patterns in Izmir and Mytilene sediment sampling sites, with highest pollution levels in the innermost Izmir sites and an overall worse pattern in Izmir vs. Mytilene sediment specimens.

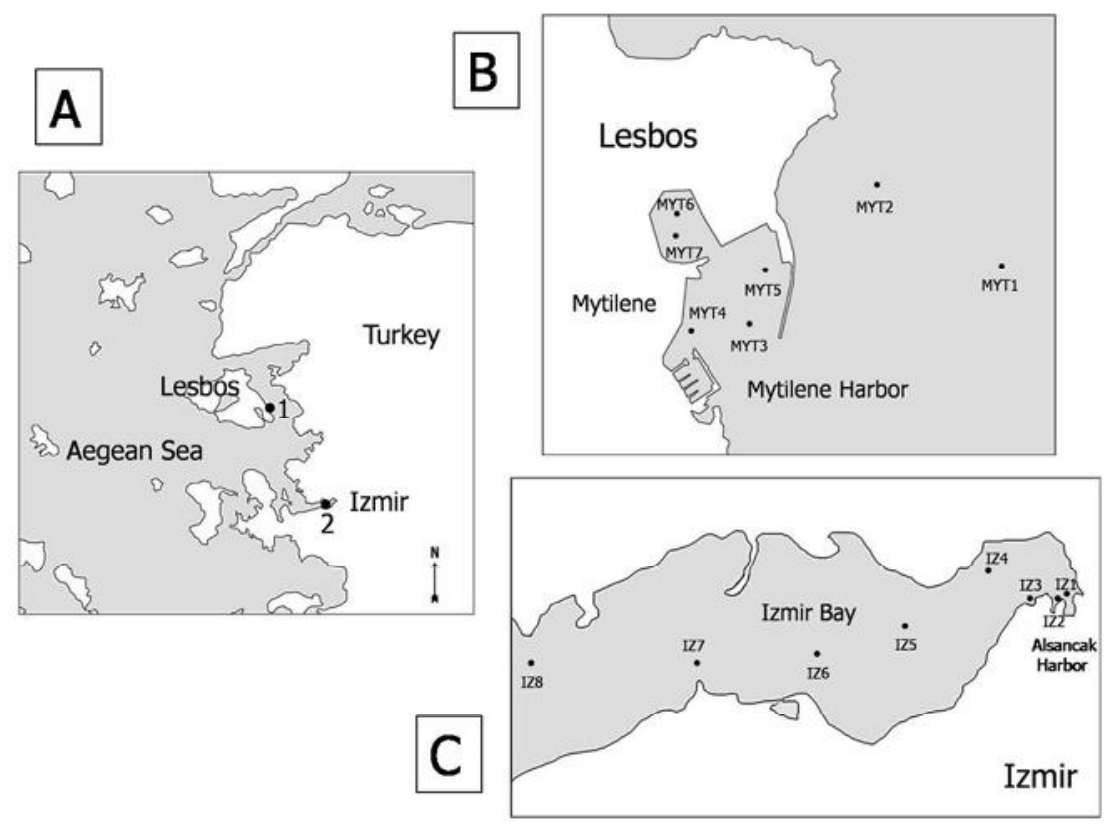

Figure 1. The study area. A. Aegean Sea; B. Mytilene Harbor; C. Izmir Bay

\section{MATERIAL AND METHODS}

\subsection{Sediment sampling sites}

\section{Mytilene harbour}

The harbor of the town of Mytilene ( 36.000 inhabitants) is the main port of Lesbos island (Greece), the third largest island of the north-eastern Aegean (Figure 1B). It is located at the eastern part of the island and its surface covers an area of about $20 \mathrm{~km}^{2}$. It comprises two sections, the inner harbor and the outer harbor, the latter being exposed to the action of frequently prevailing $\mathrm{N}-\mathrm{NE}$ winds and waves. Untreated residential and commercial effluents and town runoffs still discharged in the harbor are the main sources of water pollution in the studied area. As reported in previous studies, effluents contain important loads of organic matter, suspended solids and anthropogenic metals as it is the case for many Mediterranean towns of similar size (Aloupi and Angelidis, 2001). Although the uncontrolled discharge of untreated effluents has been decreased by a wastewater treatment plant (2001), sediments near Mytilene Harbor still carry increased loads of anthropogenic metals. The untreated sewage that still flows out in the harbor seems to affect water quality, since a higher mesotrophic character with eutrophic trends was observed in the area (Aloupi et al., 2007). Industrial activity is limited to small scale traditional plants and manufacturing.

Izmir Bay

Izmir Bay is Turkey's second largest coastal municipal area and hosts a well preserved natural harbor, which is located on the west coast of the Anatolian peninsula (Figure 1C). Izmir Bay is 
roughly 'L'-shaped with about $50 \mathrm{~km}$ in length, 2-10 km in width and with a surface of $310 \mathrm{~km}^{2}$ (Sayin, 2003). The bay consists of three sections: the Inner Bay, where Izmir port is located and extends to Yenikale lighthouses, the Middle Bay, and the Outer Bay, the latter being open to the Aegean Sea. The inner part of Izmir Bay, where Alsancak Harbor is located, has been subjected to various pollution discharges since the 1960 s and is considered to be one of the most polluted environments of the Mediterranean Sea over the last two decades. The main pollutants affecting the quality of the bay water are organic matter, nutrients, suspended matter, hydrocarbons, metals, and pathogenic organisms, all derived mainly from domestic and industrial wastes (50\%), rainfall (15\%), rivers and streams (10\%), agricultural sources (10\%) and others (15\%) (UNEP 1993). The main industries in the region include food processing, oil, soap and paint production, chemical industries, paper and pulp factories, textile industries and metal processing. According to the statistical data maintained by the Alsancak Harbor Authority in 2003, a total of 3,640 vessels approached the harbor for loading/uploading. Due to the intensive pollution in the Bay, azoic conditions have been previously reported for Izmir Bay (Muezzinoglu et al., 2000; Dogan et al., 2005).

Table 1. GPS coordinates of Izmir and Mytilene sediment sampling sites

\begin{tabular}{|c|c|c|c|c|}
\hline $\begin{array}{l}\text { Sampling } \\
\text { Stations }\end{array}$ & & depth (m) & Latitude & Longitude \\
\hline \multirow{8}{*}{ Izmir } & IZ1 & 13 & $38^{\circ} 26^{\prime} 8.07^{\prime \prime} \mathrm{N}$ & $27^{\circ}$ 9' 9.53" E \\
\hline & IZ2 & 9.6 & $38^{\circ} 26^{\prime} 7.09^{\prime \prime} \mathrm{N}$ & 27 9' 5.79" E \\
\hline & IZ3 & 9 & $38^{\circ} 26^{\prime} 7.09^{\prime \prime} \mathrm{N}$ & $27^{\circ} 9$ ' 2.55" E \\
\hline & IZ4 & 9.7 & $38^{\circ} 27^{\prime} 2.24^{\prime \prime} \mathrm{N}$ & $27^{\circ} 8^{\prime} 0.82^{\prime \prime} \mathrm{E}$ \\
\hline & IZ5 & 17.5 & $38^{\circ} 26^{\prime} 2.02^{\prime \prime} \mathrm{N}$ & $27^{\circ} 6^{\prime} 0.37^{\prime \prime} \mathrm{E}$ \\
\hline & IZ6 & 15.7 & $38^{\circ} 25^{\prime} 6.15^{\prime \prime} \mathrm{N}$ & $27^{\circ} 4^{\prime} 0.89^{\prime \prime} \mathrm{E}$ \\
\hline & IZ7 & 11 & $38^{\circ} 25^{\prime} 4.87^{\prime \prime} \mathrm{N}$ & $2700^{\prime} 9.77 " \mathrm{E}$ \\
\hline & IZ8 & 7.8 & $38^{\circ} 25^{\prime} 6.39^{\prime \prime} \mathrm{N}$ & $26^{\circ} 57^{\prime} 1.13^{\prime \prime} \mathrm{E}$ \\
\hline \multirow{7}{*}{ Mytilene } & MYT1 & 29.8 & $39^{\circ} 6^{\prime} 8.40^{\prime \prime} \mathrm{N}$ & $26^{\circ} 34^{\prime} 36.00^{\prime \prime} \mathrm{E}$ \\
\hline & MYT2 & 20.5 & $39^{\circ} 6^{\prime} 22.80^{\prime \prime} \mathrm{N}$ & $26^{\circ} 34^{\prime} 10.20^{\prime \prime} \mathrm{E}$ \\
\hline & MYT3 & 10.5 & $39^{\circ} 6^{\prime} 0.00^{\prime \prime} \mathrm{N}$ & $26^{\circ} 33^{\prime} 40.80^{\prime \prime} \mathrm{E}$ \\
\hline & MYT4 & 5.5 & $39^{\circ} 5^{\prime} 59.40^{\prime \prime} \mathrm{N}$ & $26^{\circ} 33^{\prime} 28.80^{\prime \prime} \mathrm{E}$ \\
\hline & MYT5 & 13.7 & $39^{\circ} 6^{\prime} 9.00^{\prime \prime} \mathrm{N}$ & $26^{\circ} 33^{\prime} 44.40^{\prime \prime} \mathrm{E}$ \\
\hline & MYT6 & 7.8 & $39^{\circ} 6^{\prime} 19.20^{\prime \prime} \mathrm{N}$ & $26^{\circ} 33^{\prime} 25.90^{\prime \prime} \mathrm{E}$ \\
\hline & MYT7 & 7.5 & $39^{\circ} 6^{\prime} 15.60^{\prime \prime} \mathrm{N}$ & $26^{\circ} 33^{\prime} 26.30^{\prime \prime} \mathrm{E}$ \\
\hline
\end{tabular}

\subsection{Sediment sample handling}

Surficial sediment was collected by van Veen grab samplers at the locations in Izmir Bay and Mytilene Harbor shown in Figure 1 and carried to the laboratory in refrigerated boxes. The sediment specimens were stored at $+4^{\circ} \mathrm{C}$, then mixed thoroughly and subdivided in aliquots for chemical analyses and bioassays. Sediment aliquots to be submitted to chemical analyses were dried at $60^{\circ} \mathrm{C}$ up to constant weight and then processed for inorganic or for organic analyses (see below).

\subsection{Granulometric analysis}

Grain size analysis was performed using standard sieves of $\varnothing>63 \mu \mathrm{m}$ (coarse material) and pipette method analysis for fine material according to the procedures outlined by Folk (1980). Textural sedimentary information can be reliable information to establish the risk levels of increased water turbidity in the event of marine bottom removal as well as their potential capacity to adsorb hydrophobic contaminants (Carrasco et al., 2003).

\subsection{Inorganic analysis}

The sediment samples were dried and ground to fine powder with a hardened steel mortar, thereafter a mild, non-destructive digestion procedure was carried out. One-gram powder aliquots were treated in an open flask with boiling $5 \% \mathrm{HNO}_{3}$ (ca. $10 \mathrm{~mL}$ ) for $30 \mathrm{~min}$, then filtered; solid

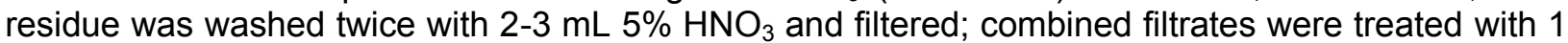
$\mathrm{mL} 30 \% \mathrm{H}_{2} \mathrm{O}_{2}$ and boiled to a volume of 3 to $4 \mathrm{~mL}$; then filtrates were treated with $20 \mathrm{~mL} \mathrm{H} \mathrm{H}_{2} \mathrm{O}, 1 \mathrm{~mL}$ $30 \% \mathrm{H}_{2} \mathrm{O}_{2}, 1 \mathrm{~mL} \mathrm{HNO}$ and boiled to a volume of 3-4 mL twice; finally it was treated with $20 \mathrm{~mL} \mathrm{H}_{2} \mathrm{O}$ 
and $1 \mathrm{~mL} \mathrm{HNO} \mathrm{H}_{3}$ and boiled up to a volume of 3-4 mL; after cooling, $20 \mathrm{~mL} \mathrm{H}_{2} \mathrm{O}$ and $1 \mathrm{~mL} \mathrm{HNO}_{3}$ were added, then diluted to $50 \mathrm{~mL}$ with water. The solutions were analyzed using Agilent Technologies 7500A ICP-MS spectrometer (Santa Clara, CA, USA), equipped with a quadrupole mass analyzer, nebulizer Babington type, glass spray chamber, quartz monobloc torch and auto-sampler. The gas flow (99.99\% Argon) used for the plasma was $15 \mathrm{~L} \mathrm{~min}^{-1}$; the auxiliary (cooling) gas flow was 1 $\mathrm{L} \mathrm{min}^{-1}$; the transport gas flow used to introduce the sample was $1.12 \mathrm{~L} \mathrm{~min}{ }^{-1}$. The radiofrequency generator worked at $1300 \mathrm{~W}$; spray chamber was constantly kept at $2^{\circ} \mathrm{C}$. The samples as well as the standards Romil ${ }^{\circledR}$ (Cambridge, UK) and Fluka ${ }^{\circledR}$ (Gillingham, Dorset, UK) ICP-MS multi-element standard solutions were analysed in a $\mathrm{HNO}_{3}$ (1 to 10\%) matrix to minimize the interferences and matrix effect. Before introducing the sample an auto-tuning sequence was implemented in order to optimize structural parameters, liquid and transport gas flows, to improve the sensitivity and mass resolution, and to limit the oxides formation and double charges, thus avoiding interferences (McCurdy and Potter 2001). The samples were fluxed in the system for a conditioning period of 2 min before the acquisition of each metal was performed (mean duration $0.5 \mathrm{sec}$ ); five repetitions were made and the final result was obtained as mean of readings. A good reproducibility was observed, within the range 3-5\% for measured elements. The accuracy (precision and trueness) of our results was calculated applying the Italian Rule UNI ISO 5725-1/2. The instrumental detection limit for ICP-MS is usually calculated as equivalent concentration corresponding to 3 times the standard deviation on the results of these measurements. (Giessmann and Greb 1994; Moens and Dams 1995). A precision of $0.5-1 \%$ for major element oxides, $2-2.5 \%$ for minor elements, $2-5$ $\%$ for trace elements of $50-150 \mathrm{ppm}, 2-10 \%$ for trace elements of $10-50 \mathrm{ppm}$ and finally $5-25 \%$ for trace elements of $0-5 \mathrm{ppm}$ was found.

Replicated measures of international reference materials (PACS2), reagent blanks, and duplicated sediment samples (about $20 \%$ of the total number of samples randomly selected from the set) were used to assess accuracy (estimated as $>95 \%$ ) and precision (estimated on triplicate samples $>93 \%$ ).

\subsection{Organic carbon}

Organic carbon was measured by Jackson-modified Walkley-Black method (Loring and Rantala, 1992). Aliquots $(0.3-0.5 \mathrm{~g})$ of homogenized, sieved $(\varnothing<2 \mathrm{~mm})$, and dried $\left(80^{\circ} \mathrm{C}\right)$ sediment were oxidized with $10 \mathrm{~mL}$ of $\mathrm{K}_{2} \mathrm{Cr}_{2} \mathrm{O}_{7} 1 \mathrm{~N}$ and $20 \mathrm{~mL}$ of concentrated $\mathrm{H}_{2} \mathrm{SO}_{4}$. Solution was back titrated with $\mathrm{Fe}\left(\mathrm{NH}_{4}\right)_{2} \mathrm{SO}_{4}$ in the presence of diphenylamine indicator (Loring and Rantala, 1992). Each measurement was carried out in duplicate.

\subsection{Polycyclic aromatic hydrocarbons (PAH)}

PAHs were measured in marine sediment samples collected from Mytilene Harbor and Izmir Bay and the following seven PAHs, included in WFD 2000/60 were determined by GC-MS: anthracene $[A]$, fluoranthene [Fluo], benzo(ghi)perylene [BPer], benzo(b)fluoranthene [BbF], benzo(k)fluoranthene $[\mathrm{BkF}]$, benzo(a)pyrene $[\mathrm{BaP}]$ and indeno(1,2,3-cd)pyrene [IP] (Kostopoulou et al. 2007). Two grams of homogenized, dried $\left(80^{\circ} \mathrm{C}\right)$ sediment was weighed directly in a centrifugation tube, where $2 \mathrm{~mL} \mathrm{CH} \mathrm{CH}_{3} \mathrm{OH}$ (Pestiscan grade), $1 \mathrm{~g}$ sodium sulphate $\left(200^{\circ} \mathrm{C}\right.$ for $\left.24 \mathrm{~h}\right)$ and $20 \mathrm{~mL} \mathrm{CH} \mathrm{Cl}_{2}$ (Pestiscan grade, Lab-Scan, Dublin, Ireland) were added and ultrasonicated (frequency $50-60 \mathrm{~Hz}$, Bransonic 2200) (Branson Ultrasonic Co., Danbury, CT, USA) at room temperature for $15 \mathrm{~min}$. The solution was left undisturbed for about $30 \mathrm{~min}$ and afterwards centrifuged at 2,500 rpm for $10 \mathrm{~min}$. The supernatant was transferred to a round bottomed flask, where activated copper was added to desulphurize the extract, reduced to a small volume (at about $1 \mathrm{~mL}$ ) using a rotary evaporator and then purified by using silica micro-columns chromatography. Elution was followed by using hexane and $\mathrm{CH}_{2} \mathrm{Cl}_{2}$, the purified extract was concentrated to a final volume of $0.5 \mathrm{~mL}$ and stored in a Teflon sealed vial at $4^{\circ} \mathrm{C}$ until analysis. The same sample preparation procedure was applied for sediments spiked with known concentrations of priority PAHs purchased from Supelco Co. (Park Bellefonte, PA, USA) and recoveries ranged from $65 \%$ to $100 \%$. The analyses were performed with a Hewlett Packard 6890GC -5973MSD (EI $70 \mathrm{eV}$ ) (GMI, Ramsey, MN, USA), equipped with a HP-5MS fused silica capillary column $30 \mathrm{~m} \times 0.25 \mathrm{~mm} \times$ $0.20 \mu \mathrm{m}$. Carrier gas was helium (purity $99.999 \%$ ) with column flow of $0.6 \mathrm{~mL} \mathrm{~min}^{-1}$. Injection was made in the splitless mode (purge delay $1 \mathrm{~min}$, purge flow $30 \mathrm{~mL} \mathrm{~min}^{-1}$ ). The oven temperature

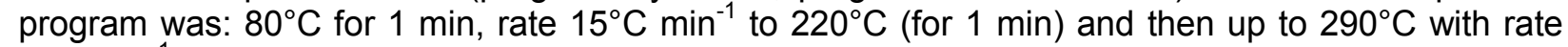
$5^{\circ} \mathrm{C} \mathrm{min}^{-1}$ (for $15 \mathrm{~min}$ ). MS source temperature was $180^{\circ} \mathrm{C}$ and transfer line $240^{\circ} \mathrm{C}$. For higher sensitivity, the analysis was performed in Selected lon Monitoring, (SIM) mode. For the instrument 
calibration, a PAHs mixture solution (Supelco Co.) was used, from which secondary standard solutions were prepared, with concentrations ranging from 5 to $400 \mu \mathrm{g} \mathrm{L}^{-1}$. R2 values for the $7 \mathrm{PAHs}$ ranged from 0.995 to 1.000 . The detection limits (LOD) for each determined compound, as well as the quantitation limits (LOQ) were calculated on the basis of signal-to-noise ratios 3 and 10 respectively.

\subsection{Statistical analysis}

The data have been analyzed using two inferential techniques, i.e.: a) test of hypothesis on means of two normal distributions, with unknown variances, and b) test of hypothesis on the variance of two normal distributions, according to Hines and Montgomery (1980). The SPSS software was utilized.

\section{RESULTS}

\subsection{Granulometric analysis}

Grain analyses results of sediments collected from Izmir Bay and Mytilene Harbor in March 2007 are shown in Table 2, where sand $(0.063-2 \mathrm{~mm})$, silt $(0.004-0.063 \mathrm{~mm})$ and clay $(<0.004 \mathrm{~mm})$ were determined.

Table 2. Organic carbon (OC, \% dw) and sediment granulometry (\%)

in surface sediments of Izmir Bay and Mytilene Harbor

\begin{tabular}{lccccc}
\hline Sampling Sites & OC & Sand & Silt & Clay & Silt \& Clay \\
\hline Location & & & & & \\
\hline IZmir & & & & & \\
\hline IZ1 & $2.3 \pm 0.5$ & 2.6 & 36.8 & 60.6 & 97.4 \\
IZ2 & $2.2 \pm 0.1$ & 19.9 & 38.2 & 41.9 & 80.1 \\
IZ3 & $2.2 \pm 0.0$ & 22.9 & 36.7 & 40.4 & 77.1 \\
IZ4 & $5.1 \pm 0.1$ & 42.6 & 25.6 & 31.7 & 57.3 \\
IZ5 & $4.7 \pm 0.3$ & 24.5 & 34.1 & 41.4 & 75.5 \\
IZ6 & $3.6 \pm 0.0$ & 17.3 & 46.4 & 36.2 & 82.6 \\
IZ7 & $1.0 \pm 0.1$ & 61.7 & 23.2 & 15.0 & 38.2 \\
IZ8 & $0.2 \pm 0.1$ & 44.2 & 33.5 & 22.3 & 55.8 \\
\hline Mytilene & & & & & \\
\hline MYT1 & $3.0 \pm 0.8$ & 59.9 & 21.6 & 18.5 & 40.1 \\
MYT2 & $3.5 \pm 0.0$ & 70 & 16.7 & 133 & 30.0 \\
MYT3 & $4.1 \pm 0.5$ & 49.3 & 26.6 & 24.1 & 50.7 \\
MYT4 & $2.8 \pm 0.0$ & 36.9 & 37.2 & 25.9 & 63.1 \\
MYT5 & $3.8 \pm 0.0$ & 17.3 & 40.0 & 42.7 & 82.7 \\
MYT6 & $2.5 \pm 0.2$ & 21.4 & 32.6 & 46.0 & 78.6 \\
MYT7 & $2.8 \pm 0.0$ & 33.8 & 37.3 & 28.9 & 66.2 \\
\hline
\end{tabular}

The percentage of silt and clay fraction of Izmir Bay ranged from $38.2 \%$ to $97.4 \%$, with the greatest values being observed in the innermost locations. According to Folk classification (1980) the sediments were classified as sandy mud (sM) and as sandy silt (sZ) with the exception of IZ7 and IZ8 sites being classified as silty sand ( $\mathrm{ZS})$.

In almost all sediment samples of the inner and the outer harbor of Mytilene the percentage of silt and clay was $>60 \%$, showing relatively low variability being classified as sandy silt (sZ) and as sandy mud (sM). Locations at the outer area (MYT1, MYT2) and at the entrance of the harbor (MYT3) were classified as muddy sand (mS) due to the lower \% of silt and clay.

\subsection{Organic carbon}

As shown in Table 2, \% OC in sediment samples from Izmir Bay and Mytilene Harbor failed to display any significant differences with the exception of IZ7 and IZ8, which presented low values. Organic carbon content at Izmir Bay locations ranged between 0.24 to $5.08 \%$ (dry wt) with a median value of $2.25 \%$. The highest values of organic carbon content are observed at the innermost locations, which are characterized by high \% of silt and clay. 
Correspondingly, organic carbon content at Mytilene Harbor locations showed values within a range of 2.5 to $4.1 \% \mathrm{dw}$ with a median value of 3.0. By comparing the data of the two areas, values of OC $(\% \mathrm{dw})$ were higher at locations subjected to human anthropogenic activities, such as waste discharges and/or urban runoffs. No statistically significant correlation between OC and grain size fractions was detected in both cases.

\subsection{Inorganic analysis}

The concentrations of a set of inorganic elements in sediment specimens from Izmir Bay and Mytilene Harbor are reported in Table 3. Concentrations of the most frequently determined metals ( $\mathrm{Zn}, \mathrm{Cu}, \mathrm{Cd}, \mathrm{Ni}, \mathrm{Cr}, \mathrm{Pb}, \mathrm{Zn}$ ) in Izmir Bay were higher in locations close to the head of the bay (IZ1 to IZ4) compared to the other locations IZ5 to IZ8. The highest values were observed for Zn (47.4 $435.2 \mu \mathrm{g} \mathrm{g}^{-1}$ dry wt), followed by $\mathrm{Cr}\left(40.9-189.5 \mu \mathrm{g} \mathrm{g}{ }^{-1}\right.$ dry wt), $\mathrm{Pb}\left(8.9-105.2 \mu \mathrm{g} \mathrm{g}^{-1}\right.$ dry wt), $\mathrm{Cu}$ $\left(13.1-95.7 \mu \mathrm{g} \mathrm{g}^{-1}\right.$ dry wt), Ti $\left(3.6-88.1 \mu \mathrm{g} \mathrm{g}{ }^{-1}\right.$ dry wt), Ni $\left(43.7-59.8 \mu \mathrm{g} \mathrm{g}{ }^{-1}\right.$ dry wt), $\mathrm{V}(13.7-34.2$ $\mu \mathrm{g} \mathrm{g}^{-1}$ dry wt), As (13.6 - $28.8 \mu \mathrm{g} \mathrm{g}^{-1}$ dry wt) and Co $\left(5.9-11.6 \mu \mathrm{g} \mathrm{g}{ }^{-1}\right.$ dry wt). Lower concentrations were found for Mo $\left(0.4-5.8 \mu \mathrm{g} \mathrm{g}^{-1}\right.$ dry wt), $\mathrm{Cd}\left(0.1-1.1 \mu \mathrm{g} \mathrm{g}{ }^{-1}\right.$ dry wt), and $\mathrm{Hg}\left(0.2-0.6 \mu \mathrm{g} \mathrm{g}^{-1}\right.$ dry wt).

By comparing the mean concentrations of trace metals in Izmir Bay vs. Mytilene Harbor, a significantly higher pollution status was detected in Izmir vs. Mytilene sediment. Iron and aluminum (Figure 2) displayed significantly higher levels in all sediment samples from Izmir vs. Mytilene samples ( $p=0.01$ both for iron and for aluminum). Manganese and zinc also showed significantly higher levels in Izmir vs. Mytilene sediment (Figure 3). Trace elements $\mathrm{As}, \mathrm{Cr}, \mathrm{Cu}, \mathrm{Pb}$ and $\mathrm{Ti}$ again showed significantly higher levels in Izmir vs. Mytilene sediment, displaying highest concentrations in sites \#IZ1 to \#IZ4, which are located at the head of the Bay (Figure 4).

Iron and Aluminum

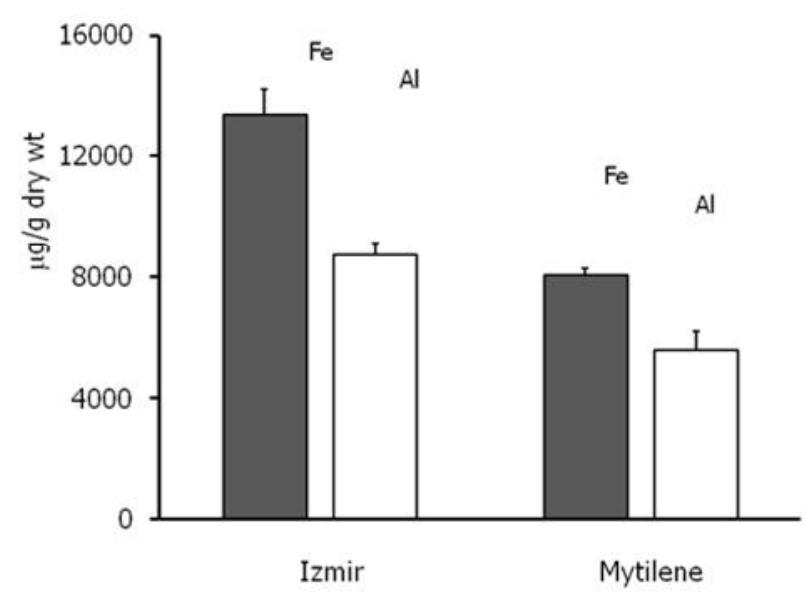

Figure 2. Concentrations of aluminum and iron $\left(\mu \mathrm{g} \mathrm{g}^{-1}\right.$ dry $\left.\mathrm{wt}\right)$ in sediment samples from Izmir and Mytilene

In Mytilene Harbor sediment, $\mathrm{Zn}$ had the highest values $\left(59.1-285.4 \mu \mathrm{g} \mathrm{g}^{-1} \mathrm{dry}\right.$ wt), followed by $\mathrm{Cr}$ $\left(29.5-125.3 \mu \mathrm{g} \mathrm{g}^{-1}\right.$ dry wt), Pb (39.4 - 69.0 $\mathrm{g} \mathrm{g}^{-1}$ dry wt), Ni $\left(30.4-56.6 \mu \mathrm{g} \mathrm{g}^{-1}\right.$ dry wt), Cu (19.0 $53.4 \mu \mathrm{g} \mathrm{g}^{-1}$ dry wt), $\mathrm{V}\left(13.8-35.8 \mu \mathrm{g} \mathrm{g}^{-1}\right.$ dry wt), Ti $\left(2.3-35.5 \mu \mathrm{g} \mathrm{g}{ }^{-1}\right.$ dry wt), As $\left(9.1-20.7 \mu \mathrm{g} \mathrm{g}^{-1}\right.$ dry wt) and Co $\left(4.4-11.8 \mu \mathrm{g} \mathrm{g}^{-1}\right.$ dry wt). Lower concentrations were found for Mo $\left(0.7-5.7 \mu \mathrm{g} \mathrm{g}^{-1}\right.$ dry wt), Cd (0.2-0.7 $\mu \mathrm{g} \mathrm{g}^{-1}$ dry wt), and $\mathrm{Hg}\left(0.3-0.4 \mu \mathrm{g} \mathrm{g}^{-1}\right.$ dry wt). 
Table 3. Concentrations ( $\mu \mathrm{g} \mathrm{g}^{-1}$ dry wt) of some selected inorganics in sediment specimens collected in Izmir (IZ) Bay and in Mytilene (MYT) Harbor. Means of quintuplicate measurements. Measurements detected the following variation ranges: $0.5-1 \%$ for major elements, 2 - $2.5 \%$ for minor elements, 2 $-5 \%$ for trace elements of $50-150$ ppm, $2-10 \%$ for trace elements of $10-50$ ppm, and $5-25 \%$ for trace elements of $0-5$ ppm

\begin{tabular}{|c|c|c|c|c|c|c|c|c|c|c|c|c|c|c|c|}
\hline Elements & Isotopes & IZ1 & IZ2 & IZ3 & IZ4 & IZ5 & IZ6 & IZ7 & IZ8 & MYT2 & MYT3 & MYT4 & MYT5 & MYT6 & MYT7 \\
\hline $\mathrm{Al}$ & $\mathrm{Al} / 27$ & 8433 & 7843 & 7396 & 8269 & 5642 & 9626 & 8068 & 9066 & 5901 & 4186 & 4581 & 8607 & 4889 & 5313 \\
\hline As & As / 75 & 24.0 & 28.8 & 28.4 & 25.8 & 14.6 & 15.5 & 13.6 & 14.1 & 9.1 & 13.7 & 14.4 & 20.7 & 11.4 & 15.1 \\
\hline $\mathrm{Be}$ & $\mathrm{Be} / 9$ & 0.72 & 0.76 & 0.67 & 0.85 & 0.50 & 0.67 & 0.57 & 0.68 & 0.45 & 0.32 & 0.45 & 0.77 & 0.37 & 0.44 \\
\hline Cd & $\mathrm{Cd} / 111$ & 0.70 & 0.51 & 0.45 & 1.07 & 0.06 & 0.40 & 0.26 & ND & 0.43 & 0.42 & 0.29 & 0.72 & 0.17 & 0.44 \\
\hline Co & Co / 59 & 9.3 & 10.5 & 9.9 & 10.3 & 5.9 & 11.2 & 11.6 & 10.1 & 5.9 & 4.4 & 4.5 & 11.8 & 5.3 & 4.5 \\
\hline $\mathrm{Cr}$ & $\mathrm{Cr} / 53$ & 82.3 & 115.1 & 78.1 & 189.5 & 44.0 & 65.6 & 40.9 & 41.3 & 36.7 & 29.5 & 32.5 & 125.3 & 33.2 & 37.3 \\
\hline $\mathrm{Cu}$ & $\mathrm{Cu} / 63$ & 66.6 & 50.8 & 49.4 & 95.7 & 13.1 & 38.5 & 21.3 & 22.4 & 19.0 & 48.9 & 29.7 & 52.0 & 19.5 & 53.4 \\
\hline $\mathrm{Fe}$ & $\mathrm{Fe} / 57$ & 14030 & 12940 & 13370 & 13770 & 8210 & 16860 & 13920 & 13850 & 7097 & 7014 & 7899 & 15090 & 6683 & 8516 \\
\hline $\mathrm{Hg}$ & $\mathrm{Hg} / 202$ & 0.31 & 0.30 & 0.35 & 0.56 & 0.17 & 0.28 & 0.25 & 0.17 & 0.29 & 0.29 & 0.28 & 0.41 & 0.33 & 0.31 \\
\hline Li & $\mathrm{Li} / 7$ & 29.0 & 33.1 & 29.8 & 24.1 & 12.3 & 22.8 & 20.0 & 20.9 & 11.9 & 7.4 & 8.2 & 22.5 & 9.6 & 9.4 \\
\hline Mg & $\mathrm{Mg} / 24$ & 14270 & 14500 & 13410 & 15180 & 17240 & 15670 & 15260 & 17710 & 18420 & 11900 & 16130 & 16700 & 16400 & 14860 \\
\hline Mn & $\mathrm{Mn} / 55$ & 316.9 & 384.9 & 400.9 & 306.3 & 160.9 & 331.7 & 414.5 & 367.1 & 150.3 & 136.8 & 145.0 & 305.4 & 138.3 & 141.4 \\
\hline Mo & Mo / 95 & 1.5 & 1.0 & 0.8 & 5.8 & 9.7 & 2.8 & 0.5 & 0.4 & 0.7 & 4.5 & 4.7 & 5.7 & 3.0 & 3.2 \\
\hline $\mathbf{N i}$ & $\mathrm{Ni} / 60$ & 49.8 & 48.4 & 43.7 & 51.3 & 55.2 & 59.8 & 58.0 & 56.9 & 46.7 & 30.4 & 38.3 & 56.6 & 42.5 & 37.0 \\
\hline $\mathrm{Pb}$ & $\mathrm{Pb} / 208$ & 105.2 & 53.41 & 46.19 & 83.92 & 8.937 & 32.73 & 22.36 & 17.15 & 43.96 & 68.96 & 39.43 & 55.43 & 42.39 & 56.12 \\
\hline $\mathrm{Sr}$ & $\mathrm{Sr} / 88$ & 212.8 & 237.4 & 241.8 & 189.7 & 610.5 & 149.5 & 183.9 & 163.2 & 581.3 & 314.7 & 606.7 & 186 & 690.2 & 381.9 \\
\hline $\mathrm{Ti}$ & $\mathrm{Ti} / 47$ & 14.09 & 7.571 & 8.202 & 18.44 & 3.622 & 39.53 & 55.81 & 88.15 & 4.432 & 10.21 & 2.321 & 35.51 & 2.64 & 4.058 \\
\hline $\mathbf{v}$ & $\mathrm{V} / 51$ & 18.15 & 14.54 & 13.71 & 31.22 & 34.24 & 28.28 & 20.09 & 22.71 & 25.23 & 13.85 & 14.04 & 35.8 & 23.17 & 15.09 \\
\hline $\mathrm{Zn}$ & $\mathrm{Zn} / 66$ & 314.6 & 244.3 & 171.5 & 435.2 & 47.43 & 159.1 & 84.73 & 75.44 & 59.09 & 172.6 & 93.09 & 285.4 & 67.16 & 160.7 \\
\hline
\end{tabular}


Manganese and Zinc

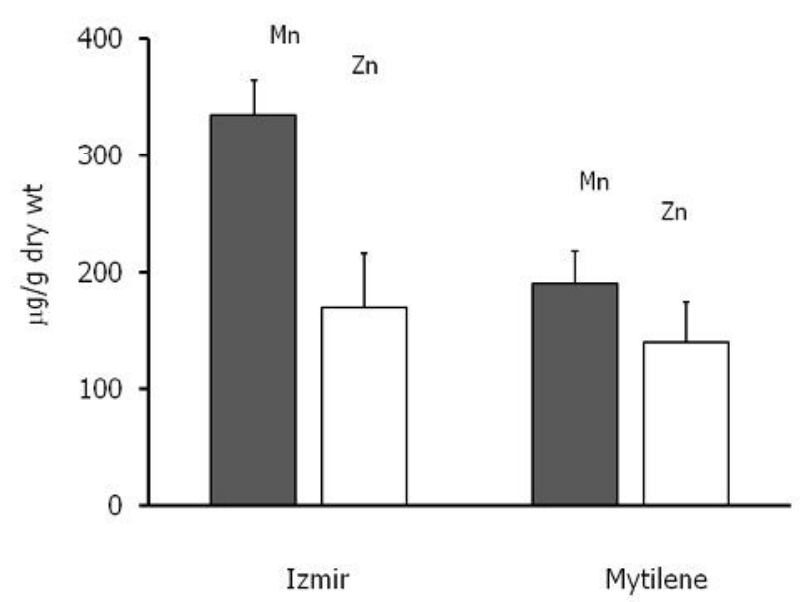

Figure 3. Concentrations of manganese and zinc $\left(\mu \mathrm{g} \mathrm{g}^{-1}\right.$ dry wt) in sediment samples from Izmir and Mytilene

Other elements

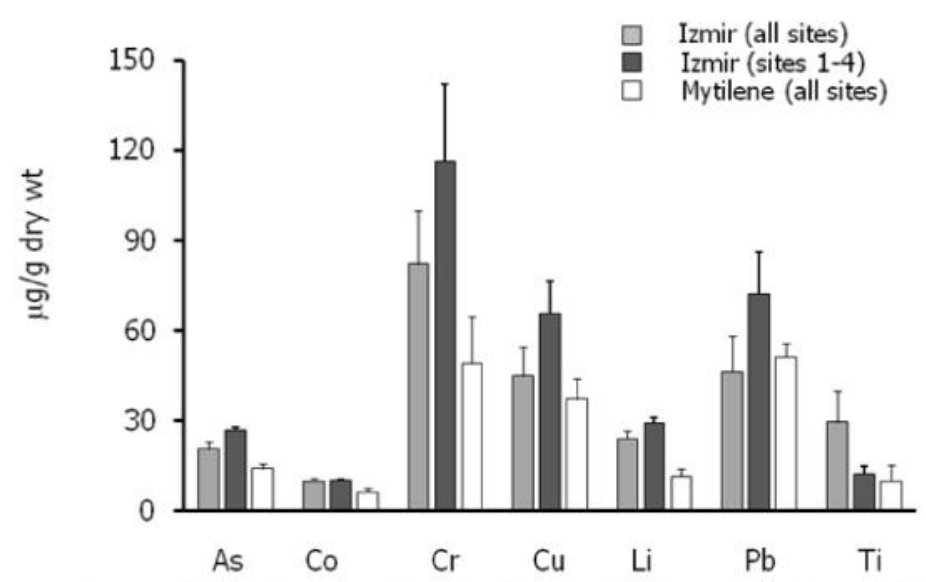

Figure 4. Concentrations of $\mathrm{As}, \mathrm{Co}, \mathrm{Cr}, \mathrm{Cu}, \mathrm{Li}, \mathrm{Pb}$ and $\mathrm{Ti}\left(\mu \mathrm{g} \mathrm{g}{ }^{-1}\right.$ dry wt) in sediment samples from Izmir and Mytilene

\subsection{Polycyclic aromatic hydrocarbons}

Concentrations values of PAHs examined ( $\Sigma 7 \mathrm{PAHs}$ ) varied for Izmir Bay sampling sites from $158 \mathrm{ng}$ $\mathrm{g}^{-1}$ to $1,575 \mathrm{ng} \mathrm{g}^{-1}$ (dry wt) with a mean value of $599 \mathrm{ng} \mathrm{g}^{-1}$. Among the eight considered sites the obtained values of concentrations of ( $\Sigma 7 \mathrm{PAHs}$ ) at IZ1, IZ2, IZ3, IZ4 and IZ5 exceeded the effect range low concentration (ERL, $552 \mathrm{ng} \mathrm{g}^{-1}$ ) reported by Long et al. (1995), which is proposed as a first warning for biological effects. Correspondingly for Mytilene Harbor values of (L7PAHs) varied from $110 \mathrm{ng} \mathrm{g}^{-1}$ to $615 \mathrm{ng} \mathrm{g}^{-1}$ (dry wt) with a mean value of $387 \mathrm{ng} \mathrm{g}^{-1}$. Values of concentrations of ( $\Sigma 7 \mathrm{PAHs}$ ) exceeding or close to the effect range low concentration (ERL, $552 \mathrm{ng} \mathrm{g}^{-1}$ ) were found for harbor locations where heavy traffic of commercial and large vessels takes place.

Sampling sites IZ2 to IZ4 showed peak values in PAH content (totaling 1,032 $\pm 480 \mathrm{ng} \mathrm{g}^{-1}$ ) that was significantly higher than either the remaining six Izmir sites $\left(311 \pm 122 \mathrm{ng} \mathrm{g}^{-1}\right)(p=0.03)$ or vs. a total of seven Mytilene sites $\left(387 \pm 172 \mathrm{ng} \mathrm{g}^{-1}\right)(p=0.012)$, as shown in Figure 5 . However, the mean concentrations of PAHs from all Izmir sites were higher, yet did not differ significantly from all Mytilene sites ( $599 \pm 451$ vs. $387 \pm 172 \mathrm{ng} \mathrm{g}^{-1}$, respectively). 
PAHs

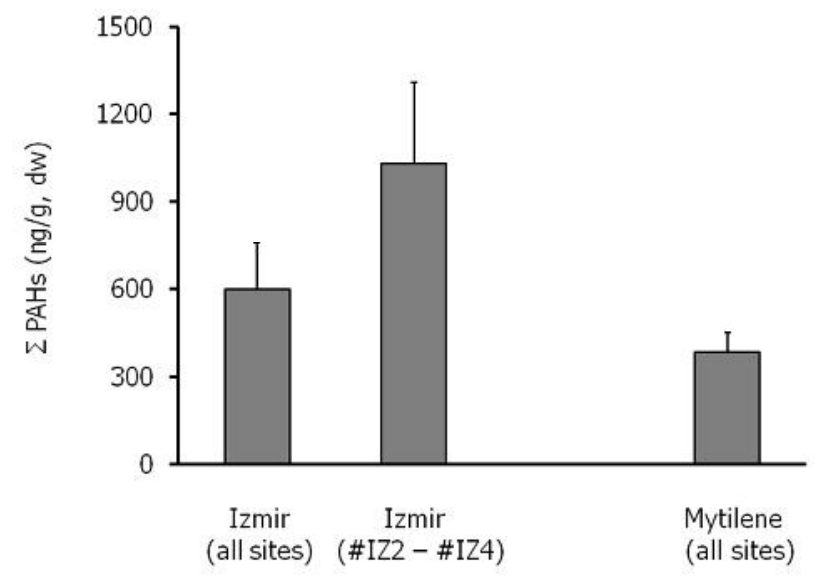

Figure 5. Concentrations of total PAHs ( 7PAHs, $\mathrm{ng} \mathrm{g}^{-1}$ dry wt) in sediment samples from Izmir and Mytilene

Among the 7 examined PAHs in Izmir sediments, fluoranthene [Fluo] and benzo(a)pyrene [BaP] were the only compounds found in all sediments at a percentage ranging from 20.2 to $21.0 \%$ and 14.8 to $17.3 \%$ of ( $27 \mathrm{PAHs})$ respectively. Benzo(b)fluoranthene [BbF], benzo(k)fluoranthene [BkF] were found in all sediment samples from Izmir Bay accounting for $30.7 \%$ of ( $27 \mathrm{PAHs}$ ), while for Mytilene Harbor sediments they were detected in locations subjected to navigation pollution.

\section{DISCUSSION}

The results provided evidence for significant differences in the pollution status between Mytilene Harbor and Izmir Bay. The differences were particularly clear-cut by considering the data from inorganic analysis and, namely, the measured levels of some anthropogenic inorganics including aluminum, iron, manganese and zinc. These findings were in agreement with other studies conducted in the bay and is attributed to the heavily industrialized and urbanized coastal area as well as to the intense marine traffic in the Alsancak Harbor (Kucuksezgin et al., 2006). In the case of chromium, copper, lead and titanium, a further difference was detected when the innermost sampling sites in Izmir Bay (\#IZ1 to \#IZ4) were considered, which displayed higher concentrations of these contaminants vs. Mytilene Harbor, in agreement with the anoxic conditions occurring in inner Izmir Bay (Ozkan et al., 2008; Bizsel and Uslu 2000). The same distinction applied to total PAHs, displaying significantly higher levels in samples from sites \#IZ2 to \#IZ4, both compared to Mytilene and to the remaining Izmir sites.

Marine sediment contamination has been investigated in Izmir Bay and other coastal areas in Turkey by a number of previous studies (UNEP, 1993; Bizsel and Uslu 2000; Kontas et al., 2004; Kucuksezgin et al., 2006; Oral et al., 2007; Esen et al., 2008; Okay et al., 2008; Guven and Akinci 2008; Ozkan et al., 2008), providing evidence for extensive anthropogenic pollution. On the other hand, sediment from Mytilene Harbor has been evaluated for metal contamination only in one report (Aloupi and Angelidis 2001), whereas no published data are available on PAH contamination in Mytilene sediment, to the best our knowledge.

Along with the topographic features and the presence of several outlets of industrial and domestic effluents, the sediment from Izmir Bay displays a clear-cut gradient of anthropogenic pollution both in terms of inorganic and of PAHs levels, from the innermost to the outer sampling sites. Unlike Izmir Bay, Mytilene Harbor failed to show any evidence for topographic differences in the levels of either inorganics or PAHs; thus we could not confirm the data by Aloupi and Angelidis (2001), who reported different lead levels in Mytilene Harbor sediment between inner and outer harbor sites. All measured levels in Mytilene sediment were invariably lower than those measured in Izmir Bay and, especially, the innermost Izmir sampling sites. The values indicate that the area at the head of Izmir 
Bay is affected by PAH contamination and the fine sediment texture, composed of high content of silt and clay facilitates the sorption of those hydrophobic contaminants (De Luca et al., 2005).

The overall contamination levels detected in sediment from Izmir Bay overlapped with the data from several polluted coastal areas and lagoons (He and Morrison, 2001; Rodríguez-Barroso et al., 2008; Accornero et al., 2008; Skoog and Arias-Esquivel 2009), whereas anthropogenic pollution in Mytilene Harbor may be regarded as a relatively marginal phenomenon.

\section{ACKNOWLEDGEMENTS}

This study was supported by NATO for Science Programme (Harbor Sediments Pollution Assessment \& Dredged Material Management, ESP.EAP.CLG 982446).

\section{REFERENCES}

Accornero A., Gnerre R. and Manfra L. (2008), Sediment concentrations of trace metals in the Berre lagoon (France): an assessment of contamination, Archives of Environmental Contamination and Toxicology, 54, 372-385.

Aksu A.E., Yaşar D. and Uslu O. (1998), Assessment of marine pollution in Izmir Bay: heavy metal and organic compound concentrations in surficial sediments, Turkish Journal of Engineering and Environmental Sciences, 22, 387-416.

Aloupi M. and Angelidis M.O. (2001), Geochemistry of natural and anthropogenic metals in the coastal sediments of the island of Lesvos, Aegean Sea, Environmental Pollution, 113, 211-219.

Aloupi M., Angelidis M.O., Gabriel A., Karantanelli M., Koulousaris M., Nikolaou N., Petsas A., Tsirtsis G., Vagi M. and Vlatsiootou F. (2007), Marine monitoring along the eastern coastal area of the island of Lesvos, Greece, during 2004 in the Framework of MEDPOL III, Global NEST Journal, 9, 83-97.

Bertolotto R.M., Ghioni F., Frignani M., Alvarado-Aguilar D., Bellucci L.G, Cuneo C., Picca M.R. and Goloo E. (2003), Polycyclic aromatic hydrocarbons in surficial coastal sediments of the Ligurian Sea, Marine Pollution Bulletin, 46, 907-913.

Bizsel N. and Uslu O. (2000), Phosphate, nitrogen and iron enrichment in the polluted Izmir Bay, Aegean Sea, Marine Environmental Research, 49, 101-122.

Bloutsos A.A., and Giannopoulos P.C. (2011) Concentrations of selected toxic elements in airborne particulates of Patras, Greece, Global NEST Journal, 13(2), 109-118.

Carrasco M., Lopez-Ramırez J.A., Benavente J., Lopez-Aguayo F. and Sales D. (2003), Assessment of urban and industrial contamination levels in the bay of Cadiz, SW Spain, Marine Pollution Bulletin, 46, 335-345.

Casado-Martinez M.C., Buceta J.L., Belzunce M.J. and Del Valls T.A. (2006), Using sediment quality guidelines for dredged material management in commercial ports from Spain, Environment International, 32, 388-396.

Chapman P.M. and Wang F. (2001), Assessing sediment contamination in estuaries, Environmental Toxicology and Chemistry, 20, 3-22.

Chapman P.M., Ho K.T., Munns W.R. Jr., Solomon K. and Weinstein M.P. (2002), Issues in sediment toxicity and ecological risk assessment, Marine Pollution Bulletin, 44, 271-278.

Chen G. and White P.A. (2004), The mutagenic hazards of aquatic sediments: a review, Mutation Research, 567, 151-225.

Darilmaz E. and Kucuksezgin F. (2007), Distribution and origin of hydrocarbons in surficial sediments from the eastern Aegean Sea (Izmir Bay), Marine Pollution Bulletin, 54, 1824-1830.

De Luca G., Furesi A., Micera G., Panzanelli A., Piu, P.C., Pilo M.I., Spano N. And Sanna G. (2005), Nature, distribution and origin of polycyclic aromatic hydrocarbons (PAHs) in the sediments of Olbia harbor (Northern Sardinia, Italy), Marine Pollution Bulletin, 50, 1223-1232.

Díez S. and Bayona J.M. (2009), Butyltin occurrence and risk assessment in the sediments of the lberian Peninsula, Journal of Environmental Management, 90 (Suppl 1), S25-30.

Dogan A., Cinar M. E., Onen M., Ergen Z. and Katagan T. (2005), Seasonal analysis of soft bottom zoobenthic communities in polluted and unpolluted areas of Izmir Bay (Aegean Sea), Senckenbergiana Maritima, 35, 133-145.

Esen E., Kucuksezgin F. and Uluturhan E. (2010), Assessment of trace metal pollution in surface sediments of Nemrut Bay, Aegean Sea, Environmental Monitoring and Assessment, 160, 257-266. 
European Commission (2000), Directive of the European Parliament and of the Council 2000/60/EC establishing a framework for community action in the field of water policy, Official Journal, C513 $23 / 10 / 2000$.

Folk R.L. (1980), Petrology of the Sedimentary Rocks (2nd Edition). Hemphill Publishing Company, Austin, Texas, USA $182 \mathrm{pp}$.

Giessmann U. and Greb U. (1994), High resolution ICP-MS, a new concept for elemental mass spectrometry, Fresenius Journal of Analytical Chemistry, 350, 186-193.

Guven D.E. and Akinci G. (2008), Heavy metals partitioning in the sediments of Izmir Inner Bay, Journal of Environmental Sciences, 20, 413-418.

Hines W.W. and Montgomery D.C. (1980), Probability and Statistics in Engineering and Management Science. John Wiley \& Sons, New York, NY, USA, 634 pp.

He Z. and Morrison R.J. (2001), Changes in the marine environment of Port Kembla Harbour, NSW, Australia, 1975-1995: a review, Marine Pollution Bulletin, 42, 193-201.

Ho K.T., Burgess R.M., Pelletier M.C., Serbst J.R., Ryba S.A., Cantwell M.G., Kuhn A. and Raczelowski P. (2002), An overview of toxicant identification in sediments and dredged materials, Marine Pollution Bulletin, 44, 286-293.

Kalantzi O.I. and Alcock R.A. (2012), Short-chain chlorinated paraffins in biota - levels and effects, Global NEST Journal, 14(1), 66-71.

Kanaki M., Nikolaou A., Makri, C. and Lekkas D.F. (2007), The occurrence of priority PAHs, nonylphenol and octylphenol in inland and coastal waters in Athens and Mytilene, Greece, Desalination, 210, 1623.

Khairy M.A., Kolb M., Mostafa A.R., El-Fiky A. and Bahadir M. (2009), Risk assessment of polycyclic aromatic hydrocarbons in a Mediterranean semi-enclosed basin affected by human activities (Abu Qir Bay, Egypt), Journal of Hazardous Materials, 170, 389-397.

Kontas A., Kucuksezgin F., Altay O. and Uluturhan E. (2004), Monitoring of eutrophication and nutrient limitation in the Izmir Bay (Turkey) before and after wastewater treatment plant, Environment International, 29, 1057-1062.

Kontas A. (2006), Mercury in the Izmir Bay: An assessment of contamination, Journal of Marine Systems, 61, 67-78.

Kostopoulou M., Mylona A., Nikolaou A., Lofrano G., Meric S. and Belgiorno V. (2007), Determination of the aromatic polycyclic hydrocarbons in the harbour sediments of Mytilene, Greece, Proceeding of $10^{\text {th }}$ International Conference of Environmental Science and Technology, 5-7 September, Kos, Greece, Vol A:723-726.

Kucuksezgin F., Kontas A., Altay O., Uluturhan E. and Darilmaz E. (2006), Assessment of marine pollution in Izmir Bay: Nutrient, heavy metal and total hydrocarbon concentrations, Environment International, 32, 41-51.

Lipiatou E., Tolosa I., Simó R., Bouloubassi I., Dachs J., Marti S., Sicre M.A., Bayona J.M., Grimalt J.O., Saliott A. and Albaiges J. (1997), Mass budget and dynamics of polycyclic aromatic hydrocarbons in the Mediterranean Sea, Deep Sea Research Part II: Topical Studies in Oceanography, 44, 881-905.

Long E.R., McDonald D.D., Smith S.L. and Calder F.D. (1995), Incidence of adverse biological effects within ranges of chemical concentrations in marine and estuarine sediments, Environmental Management, 19, 81-97.

Loring D.H. and Rantala R.T.T. (1992), Manual for the geochemical analyses of marine sediments and suspended particulate matter, Earth-Science Reviews, 32, 235-283.

Martin J., Sanchez-Cabeza J.A., Eriksson M., Levy I. and Miquel J.C. (2009), Recent accumulation of trace metals in sediments at the DYFAMED site (Northwestern Mediterranean Sea), Marine Pollution Bulletin, 59, 146-153.

McCurdy E. and Potter D. (2001), Optimising ICP-MS for the determination of trace metals in high matrix samples, Spectroscopy Europe, 13,14-20.

Moens L. and Dams R. (1995), NAA and ICP-MS: a comparison between two methods for trace and ultratrace element analysis, Journal of Radioanalytical and Nuclear Chemistry, 192, 29-38.

Muezzinoglu A., Sponza D., Koken I., Alparslan N., Akyarlı A. and Oztüre N. (2000), Hydrogen sulfide and odour control in Izmir Bay, Water, Air and Soil Pollution, 123, 245-257.

Okay O.S., Pekey H., Morkoc E., Basak S. and Baykal B. (2008), Metals in the surface sediments of Istanbul Strait (Turkey), Journal of Environmental Science and Health, Part A: Toxic / Hazardous Substances and Environmental Engineering, 43, 1725-1734. 
Oral R., Parlak H., Boyacıoğlu M., Cakal Arslan O. and Kucuksezgin F. (2007), An assessment of sediment quality at the streams flowing into Izmir Bay, Aegean Sea, Turkey, Pakistan Journal Biological Science, 10, 1738-1742.

Ozkan E.Y., Kocatas A. and Buyukisik B. (2008), Nutrient dynamics between sediment and overlying water in the inner part of Izmir Bay, Eastern Aegean, Environmental Monitoring and Assessment, 143, 313-325.

Pagano G., Korkina L.G., laccarino M., De Biase A., Deeva I.B., Doronin Y.K., Guida M., Melluso, G., Meriç S., Oral R., Trieff N.M. and Warnau M. (2001), Developmental, cytogenetic and biochemical effects of spiked or environmentally polluted sediments in sea urchin bioassays. In: Biomarkers in marine ecosystems: A practical approach, Garrigues, P., Walker, C.H. and Barth, H. (Eds.), Elsevier, Amsterdam, The Netherlands, pp. 85-129.

Petreas M., Park J.S., Wang M., Wang Y., Guo W., Tarrant A., Rhee A. and Harwani S. (2012), The California Biomonitoring Program: persistent organic pollutants in archived and contemporary serum, Global NEST Journal, 14(1), 80-85.

Rodríguez-Barroso M.R., Benhamou Y., El Moumni B., El Hatimi I. and García-Morales J.L. (2008), Evaluation of metal contamination in sediments from north of Morocco: geochemical and statistical approaches, Environmental Monitoring and Assessment, 159, 169-181.

Savvidis Y.G., Patoucheas D.P., Nikolaidis G. and Koutitas C.G. (2011) Modelling the dispersion of harmful algal bloom (HAB) in the Thermaikos Gulf (NW Aegean Sea), Global NEST Journal, 13(2), $119-130$.

Sayin E. (2003), Physical features of the Izmir Bay, Continental Shelf Research, 23, 957-970.

Skoog, A. C. and Arias-Esquivel V.A. (2009), The effect of induced anoxia and reoxygenation on benthic fluxes of organic carbon, phosphate, iron, and manganese, Science of Total Environment, 407, 6085-6092.

Sunlu, U., Aksu, M., Buyukisik B. and Sunlu F.S. (2008), Spatio-temporal variations of organic carbon and chlorophyll degradation products in the surficial sediments of Izmir Bay (Aegean Sea/Turkey), Environmental Monitoring and Assessment, 146, 423-432.

Thomaidis N.S., Asimakopoulos A.G., and Bletsou A.A. (2012), Emerging contaminants: a tutorial minireview, Global NEST Journal, 14(1), 72-79.

UNEP (1993), Costs and Benefits of Measures for the Reduction of Degradation of the Environment from Land-based Sources of Pollution in Coastal Areas. A - Case Study of the Bay of Izmir. B - Case Study of the Island of Rhodes, MAP Technical Reports Series No. 72, UNEP, Athens, 64 pp. 